\title{
Impact of Public Health Interventions on Drinking Water-Associated Outbreaks of Hepatitis A — United States, 1971-2017
}

\author{
Catherine E. Barrett, $\mathrm{PhD}^{1}$; Bryn J. Pape, $\mathrm{DO}^{1}$; Katharine M. Benedict, PhD, DVM¹; Monique A. Foster, MD²; Virginia A. Roberts, MSPH${ }^{1}$;
} Kenneth Rotert, $\mathrm{MS}^{3}$; Mia C. Mattioli, $\mathrm{PhD}^{1}$; Jonathan S. Yoder, $\mathrm{MPH}, \mathrm{MSW}^{1}$

Hepatitis A virus (HAV) is an RNA virus primarily transmitted via the fecal-oral route and, in rare cases, causes liver failure and death in infected persons. Although drinking waterassociated hepatitis A outbreaks in the United States are rarely reported (1), HAV was the most commonly reported etiology for outbreaks associated with untreated ground water during 1971-2008 (2), and HAV can remain infectious in water for months (3). This report analyzes drinking water-associated hepatitis A outbreaks reported to the Waterborne Disease and Outbreak Surveillance System (WBDOSS) during 1971-2017. During that period, 32 outbreaks resulting in 857 cases were reported, all before 2010. Untreated ground water was associated with $23(72 \%)$ outbreaks, resulting in $585(68.3 \%)$ reported cases. Reported outbreaks significantly decreased after introduction of Advisory Committee on Immunization Practices (ACIP) hepatitis A vaccination recommendations* and U.S. Environmental Protection Agency's (USEPA) public ground water system regulations. ${ }^{\dagger}$ Individual water systems, which are not required to meet national drinking water standards, ${ }^{\S}$ were the only contaminated drinking water systems

\footnotetext{
* ACIP issued hepatitis A vaccination recommendations in 1996 to populations at risk (https://www.cdc.gov/mmwr/preview/mmwrhtml/00048084.htm). In 1999, ACIP recommendations were expanded to western states with high incidence of hepatitis A (https://www.cdc.gov/mmwr/preview/mmwrhtml/ rr4812a1.htm). In 2006, hepatitis A vaccine became part of the routine childhood immunization schedule (https:/www.cdc.gov/mmwr/preview/ mmwrhtml/rr5507a1.htm).

†USEPA’s 1989 Total Coliform Rule and Surface Water Treatment Rule, 2013 Revised Total Coliform Rule, and 2006 Ground Water Rule provide regulations for public ground water systems at risk for contamination. The 2006 Ground Water Rule requires certain public water systems using ground water sources and not providing 4-log virus treatment to monitor ground water sources for indicators of fecal contamination and to provide corrective actions for those sources where these indicators are detected (https://www.epa.gov/dwreginfo/ ground-water-rule). Monitoring of source waters under the Ground Water Rule is triggered by the presence of total coliforms in the drinking water distribution system as monitored under the Revised Total Coliform Rule. The Total Coliform Rule of 1989 (along with its 2013 revision) requires monitoring of microbial indicators for the potential for fecal contamination (https://www.epa.gov/ dwreginfo/revised-total-coliform-rule-and-total-coliform-rule). USEPA published the Revised Total Coliform Rule in 2013. The 1989 Surface Water Treatment Rule includes identification of ground water systems that are under the direct influence of surface water (https://www.epa.gov/dwreginfo/surfacewater-treatment-rules). Systems under the Surface Water Treatment Rule are required to filter and disinfect water sources, although some water systems are allowed to use disinfection only for surface water sources that meet criteria for water quality and watershed protection. States have 3 years to implement USEPA rules from the date of promulgation.

${ }^{\S}$ National primary drinking water regulations, 40 C.F.R. Sect. 141 (1998).
}

to cause the last four reported hepatitis A outbreaks during 1995-2009. No waterborne outbreaks were reported during 2009-2017. Water testing and treatment are important considerations to protect persons who use these unregulated systems from HAV infection.

U.S. states and territories have voluntarily reported waterborne disease outbreaks to WBDOSS since 1971.9 Waterborne hepatitis A outbreaks (1971-2017) reported as of March 13, 2018, were reviewed. An outbreak of hepatitis A was defined as two or more cases of HAV infection epidemiologically linked by time and location of water exposure. To compare occurrence with other waterborne exposure pathways, outbreaks reviewed included those caused by drinking, recreational, environmental (i.e., nondrinking, nonrecreational water), or undetermined water exposures. ${ }^{* *}$ As described previously (1), data reviewed included location; date of first illness; estimated number of primary cases, hospitalizations, and deaths; water system type according to USEPA Safe Drinking Water Act definitions (i.e., community, noncommunity, and individual); setting of exposure; drinking water sources (i.e., ground water, surface water, and unknown); and water system characteristics. ${ }^{\dagger \dagger}$ Community and noncommunity water systems are public water systems that have 15 or more service connections or serve an average of 25 or more residents for $\geq 60$ days per year. ${ }^{\$ \$}$ A community water system serves year-round residents of a community, subdivision, or mobile home park. A noncommunity water system serves an institution, industry, camp, park, hotel, or business. Individual water systems are small systems (e.g., private wells

\footnotetext{
I Outbreak reports can be submitted by public health agencies in the U.S states, District of Columbia, Federated States of Micronesia, Guam, Marshall Islands, Northern Mariana Islands, Palau, Puerto Rico, and U.S. Virgin Islands https:// www.cdc.gov/healthywater/surveillance/tracking-systems.html.

** Drinking water, also called potable water, is water for human consumption (e.g., drinking, bathing, showering, handwashing, tooth brushing, food preparation, dishwashing, and maintaining oral hygiene) and includes water collected, treated, stored, or distributed in public and individual water systems, as well as bottled water. More information on recreational, environmental, and other water exposures is available at https://www.cdc.gov/nors/pdf/ CDC_5212_guidance.pdf.

$t \dagger$ Outbreak reports through 2014 have been assigned water system characteristics according to information from previous reviews by CDC and USEPA. The characteristics provide information regarding how the water became contaminated and factors leading to waterborne disease outbreaks. https:// www.cdc.gov/healthywater/surveillance/deficiency-classification.html.

$\$ \$$ https://www.epa.gov/dwreginfo/information-about-public-water-systems.
} 
and springs) not owned or operated by a water utility that have fewer than 15 connections or serve fewer than 25 persons. The number of outbreaks before and after public health interventions were compared; chi-squared tests were used to identify significant ( $\mathrm{p}$-value $<0.05)$ differences. Data were analyzed using SAS software (version 9.4; SAS Institute) and visualized in ArcGIS (version 10.6.1; Environmental Systems Research Institute).

Thirty-two drinking water-associated hepatitis A outbreaks were reported to CDC during 1971-2017; the last one occurred in 2009 (Table). These drinking water-associated outbreaks accounted for 857 cases (range $=2-50$ ), with no reported deaths. Data on number of deaths were unavailable for three outbreaks. Data on hospitalizations were unavailable for all outbreaks. Outbreaks occurred in 18 states, all in the lower continental United States (Figure 1). One environmental outbreak (1975) and one recreational water outbreak (1989) were reported during this period, but were excluded from this analysis.

The most commonly reported water system type associated with an outbreak was individual, accounting for 13 of 32 (41\%) outbreaks and 257 of 857 (30.0\%) cases, followed by community (10 [31\%] outbreaks; 241 [28.1\%] cases) and

TABLE. Hepatitis A drinking water-associated outbreaks $(\mathrm{N}=32)$, by year and month of first case onset - Waterborne Disease and Outbreak Surveillance System, United States, 1971-2017

\begin{tabular}{|c|c|c|c|c|c|c|c|c|}
\hline Year & Month & State & $\begin{array}{l}\text { No. of } \\
\text { cases* }\end{array}$ & $\begin{array}{c}\text { Type of water } \\
\text { system }\end{array}$ & Setting & $\begin{array}{l}\text { Drinking water } \\
\text { source }\end{array}$ & $\begin{array}{l}\text { Drinking water } \\
\text { description }\end{array}$ & $\begin{array}{l}\text { Water system } \\
\text { characteristic }^{\S}\end{array}$ \\
\hline 1971 & Jun & Arkansas & 98 & Noncommunity & Store/Shop & Ground water & Well & No treatment \\
\hline 1971 & Jul & New Jersey & 22 & Noncommunity & Camp/Cabin setting & Ground water & Well & No treatment \\
\hline 1971 & Aug & Oklahoma & 6 & Individual & Unknown & Ground water & Well & No treatment \\
\hline 1971 & Sep & North Carolina & 2 & Individual & Private residence & Ground water & Well & No treatment \\
\hline 1971 & Nov & Oklahoma & 50 & Community & Community/Municipality & Ground water & Spring & Treatment deficiency \\
\hline 1971 & Nov & Texas & 3 & Individual & Farm/Agricultural setting & Ground water & Well & No treatment \\
\hline 1972 & May & Ohio & 9 & Community & Mobile home park & Ground water & Unknown & Distribution system deficiency \\
\hline 1972 & Jul & Ohio & 12 & Community & Unknown & Ground water & Spring & No treatment \\
\hline 1972 & Jul & Pennsylvania & 5 & Noncommunity & Camp/Cabin setting & Ground water & Well & No treatment \\
\hline 1972 & Aug & Alabama & 9 & Community & Community/Municipality & Ground water & Spring & No treatment \\
\hline 1972 & Oct & Alabama & 50 & Noncommunity & School/College/University & Ground water & Spring & Treatment deficiency \\
\hline 1973 & Feb & Alabama & 50 & Community & Community/Municipality & Ground water & Well & Treatment deficiency \\
\hline 1973 & Jul & Ohio & 35 & Noncommunity & Park & Ground water & Spring & No treatment \\
\hline 1977 & Jul & South Carolina & 47 & Noncommunity & Factory/Industrial facility & Unknown & Unknown & Distribution system deficiency \\
\hline $1980^{\text {ๆ }}$ & Jul & Wisconsin & 12 & Individual & Factory/Industrial facility & Ground water & Well & No treatment \\
\hline 1980 & Aug & Pennsylvania & 48 & Noncommunity & Community/Municipality & Ground water & Well & Treatment deficiency \\
\hline 1982 & Jun & Georgia & 10 & Individual & Child care facility & Ground water & Well & No treatment \\
\hline 1982 & Jul & Georgia & 35 & Community & Mobile home park & Ground water & Well & No treatment \\
\hline 1982 & Nov & Kentucky & 58 & Community & Community/Municipality & Ground water & Spring & No treatment \\
\hline 1983 & Jun & Tennessee & 8 & Noncommunity & Church/Place of Worship & Ground water & Spring & No treatment \\
\hline 1983 & Sep & Kentucky & 150 & Individual & Community/Municipality & Ground water & Well & No treatment \\
\hline 1983 & Nov & California & 6 & Community & American Indian reservation & Surface water & River/Stream & Treatment deficiency \\
\hline 1984 & Sep & Massachusetts & 7 & Individual & Private residence & Ground water & Well & No treatment \\
\hline 1988 & Sep & Washington & 9 & Community & Mobile home park & Ground water & Well & Treatment deficiency \\
\hline 1990 & May & Pennsylvania & 22 & Individual & Private residence & Ground water & Well & No treatment \\
\hline 1990 & Nov & Pennsylvania & 3 & Community & Community/Municipality & Ground water & Well & Treatment deficiency \\
\hline 1992 & Apr & Missouri & 46 & Noncommunity & School/College/University & Ground water & Well & No treatment \\
\hline 1992 & Jun & Washington & 10 & Individual & Private residence & Ground water & Well & No treatment \\
\hline 1995 & Sep & Tennessee & 8 & Individual & Private residence & Ground water & Spring and Well & No treatment \\
\hline 2006 & Jul & North Carolina & 16 & Individual & Private residence & Ground water & Spring & No treatment \\
\hline 2008 & Mar & Tennessee & 9 & Individual & Community/Municipality & Ground water & Well & No treatment \\
\hline 2009 & Jul & Maine & 2 & Individual & Private residence & Ground water & Well & No treatment \\
\hline
\end{tabular}

* Number of estimated primary cases.

+ Community and noncommunity water systems are public water systems that have 15 or more service connections or serve an average of 25 or more residents for $\geq 60$ days per year. A community water system serves year-round residents of a community, subdivision, or mobile home park. A noncommunity water system serves an institution, industry, camp, park, hotel, or business and can be nontransient or transient. Nontransient systems serve 25 or more of the same persons for $\geq 6$ months of the year but not year-round (e.g., factories and schools). Transient systems provide water to places in which persons do not remain for long periods (e.g., restaurants, highway rest stations, and parks). Individual water systems are small systems not owned or operated by a water utility that have fewer than 15 connections or serve fewer than 25 persons.

$\S$ Waterborne disease outbreak reports through 2014 have been assigned one or more water system characteristics according to information from previous reviews by CDC and USEPA. These characteristics summarize information about how the water became contaminated and factors leading to waterborne disease outbreaks https://www.cdc.gov/healthywater/surveillance/deficiency-classification.html. Characteristics described here include 1) no treatment (untreated ground water); 2) treatment deficiency (e.g., temporary interruption of disinfection, chronically inadequate disinfection, or inadequate or no filtration); and 3) distribution system deficiency (e.g, storage issues such as cross-connection, backflow, contamination of water mains during construction or repair).

I This outbreak was assigned two etiologies (hepatitis A virus and an unidentified agent causing acute gastrointestinal illness). 
FIGURE 1. Reported drinking water-associated hepatitis A outbreaks $(\mathrm{N}=32)$, by state - Waterborne Disease and Outbreak Surveillance System, United States, 1971-2017

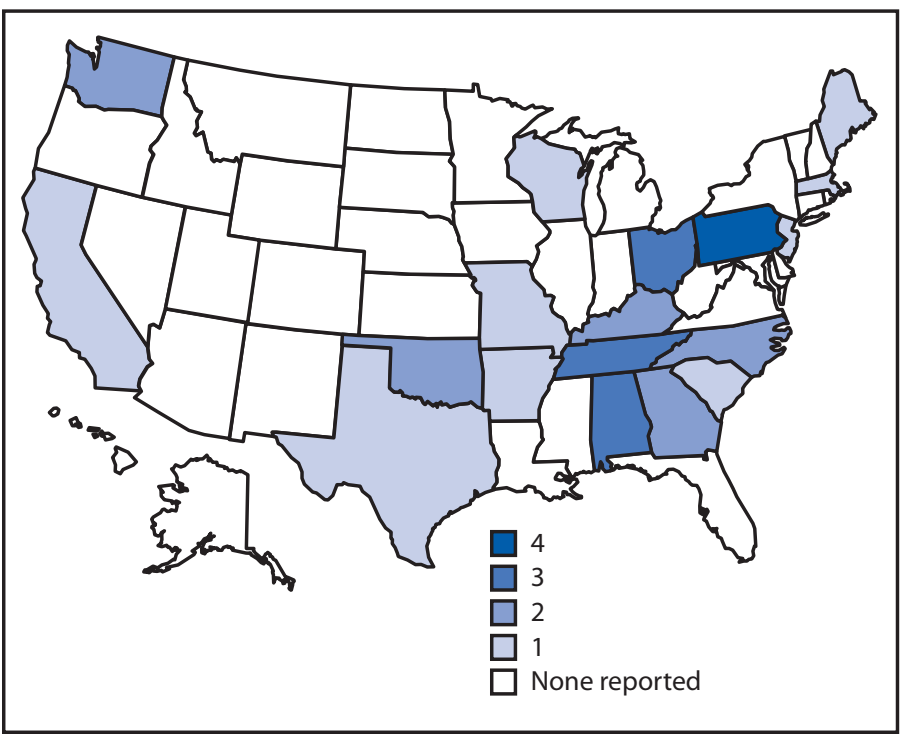

noncommunity (9 [28\%] outbreaks; 359 [41.9\%] cases). All individual water systems with outbreaks were supplied by private wells or springs. The majority of all drinking water outbreaks and cases were associated with systems supplied by ground water (30 [94\%] outbreaks; 804 [93.8\%] cases) and with an absence of water treatment (23 [72\%] outbreaks; 585 [68.3\%] cases).

The incidence of reported drinking water-associated hepatitis A outbreaks significantly decreased after introduction of the 1989 USEPA Total Coliform and Surface Water Treatment Rules (77\% decline from 1971-1989 [24 outbreaks] to 19902017 [eight]; $p=0.003$ ), the 1996 ACIP hepatitis A vaccination recommendations (87\% decline from 1971-1996 [29] to $1997-2017$ [three]; $\mathrm{p}<0.001$ ), and the 2006 Ground Water Rule and expanded ACIP vaccine recommendations (78\% decline from 1971-2006 [30] to 2007-2017 [two]; $\mathrm{p}=0.038$ ) (Figure 2). From 1995 through 2009, all four hepatitis A drinking water-associated outbreaks, resulting in 35 cases, were attributed to individual water systems using untreated ground water sources. No water-associated hepatitis A outbreaks have been reported since July 2009.

\section{Discussion}

Reported drinking water-associated hepatitis A outbreaks have declined since reporting began in 1971, and none have been reported since 2009, mirroring the overall decline in U.S. cases $(4,5)$. Vaccination for hepatitis A, combined with USEPA regulations that require testing and, where necessary, corrective actions or treatment for drinking water supplies, likely played a role in reducing reported hepatitis A drinking water-associated outbreaks.

Vaccination efforts have led to significant changes in hepatitis A epidemiology $(4,6,7)$. HAV infection rates in the United States have decreased since the introduction of hepatitis A vaccine in 1995 (4,5). Vaccine recommendations were originally targeted to children in communities with high rates of hepatitis A infections west of the Mississippi and other groups at risk (e.g., international travelers, men who have sex with men, illicit drug users, persons with clotting factor disorders, and persons with occupational risk). By 2006, routine hepatitis A vaccination was recommended for all children aged $\geq 1$ year regardless of geographic area of residence (5). Although vaccination was never recommended for users of individual ground water systems, this group likely benefited from the recommendations targeting children and other groups at risk. Incidence of HAV infection is now lowest among persons aged 0-19 years (4). However, the proportion of HAV-associated hospitalizations steadily increased during 1999-2011, likely because of more severe disease in older adults, with persons aged $\geq 80$ years experiencing the highest rates of infection $(G)$. The number of hepatitis A cases in the United States reported to CDC increased by $294 \%$ during 2016-2018, compared with the period 2013-2015 (8), primarily because of community-wide outbreaks in persons reporting homelessness or drug use ( 7 ). ACIP recommends vaccination to persons who use drugs and recently expanded recommendations to persons experiencing homelessness. 99

Reported drinking water-associated hepatitis A outbreaks were most commonly linked to individual water systems that used wells with untreated ground water. Recreational and environmental outbreaks were only reported twice, suggesting that drinking water is a more common waterborne exposure pathway for hepatitis A. Nearly 43 million U.S. residents, or $13 \%$ of the population, are served by individual water systems, primarily from ground water sources (https://pubs.er.usgs. gov/publication/cir1441). Untreated ground water sources were associated with $30 \%$ of all drinking water-associated outbreaks reported to CDC during 1971-2008 (1). The USEPA Total Coliform and Surface Water Treatment Rules of 1989 and Ground Water Rule of 2006 provide enhanced safety measures for public water systems using ground water sources and might have contributed to the absence of reported hepatitis A outbreaks linked to community water sources since 1990. However, federal regulations do not apply to individual water systems, which often have inadequate or no water treatment (9). Private wells or springs were the only

\footnotetext{
99 https:/www.cdc.gov/mmwr/volumes/68/wr/mm6806a6.htm.
} 
FIGURE 2. Reported drinking water-associated hepatitis A outbreaks $(\mathrm{N}=32)$, by year, and case incidence of reported hepatitis $A$ virus infections, by year — United States, 1971-2017* and 1971-2016 ${ }^{\dagger}$

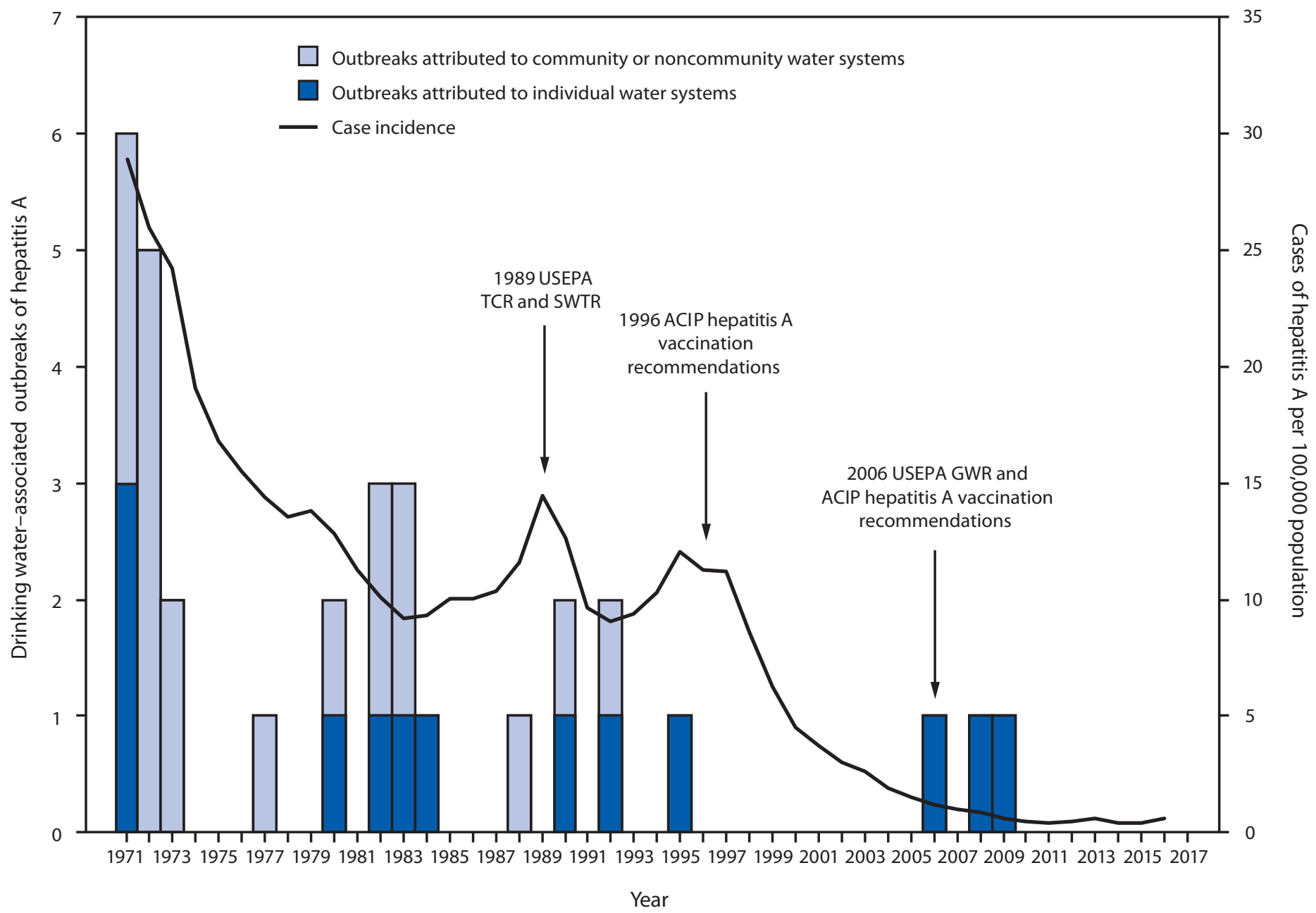

Abbreviations: ACIP = Advisory Committee on Immunization Practices; GWR = Ground Water Rule; SWTR = Surface Water Treatment Rule; TCR = Total Coliform Rule; USEPA = U.S. Environmental Protection Agency.

* Waterborne Disease and Outbreak Surveillance System.

${ }^{\dagger}$ National Notifiable Disease Surveillance System. Adapted from Murphy, TV, Denniston MM, Hill HA, et al. (https://www.cdc.gov/hepatitis/statistics/SurveillanceRpts.htm).

contaminated drinking water systems to cause the last four reported hepatitis A outbreaks during 1995-2009. CDC recommends that owners of private wells test their water annually for indicators of fecal contamination (https://www. cdc.gov/healthywater/drinking/private/wells/testing.html). Factors contributing to fecal contamination of ground water include nearby septic systems or sewage, weather patterns (e.g., heavy rainfall), improper well construction and maintenance, surface water seepage, and hydrogeologic formations (e.g., karst limestone) that allow for rapid pathogen transport $(2,9)$.

The findings in this report are subject to at least three limitations. First, waterborne hepatitis A outbreak reporting is through a passive, voluntary surveillance system; health departments have varying capacity to detect, investigate, and report outbreaks, which might result in incomplete data on outbreak occurrence and characteristics within and across jurisdictions. Thus, outbreak surveillance data might underestimate the actual number of drinking water-associated hepatitis A outbreaks and might underreport information regarding health outcomes such as cases of illness. Second, attributing the source of an outbreak to individual water systems can be particularly difficult because hepatitis A can also be spread through personto-person transmission within a household. Finally, outbreak data before 2009 did not include case-specific information; thus, demographic factors, including age, could not be assessed.

Drinking water-associated hepatitis A outbreaks have declined and essentially stopped, likely in large part because of the introduction of an efficacious vaccine as part of the 


\section{Summary}

What is already known about this topic?

Waterborne hepatitis A outbreaks have been reported to CDC. Person-to-person transmission of hepatitis $A$ has increased in recent years.

What is added by this report?

Reported drinking water-associated hepatitis A outbreaks have declined since introduction of universal childhood vaccination recommendations and public drinking water regulations. However, unvaccinated persons who use water from untreated private wells remain at risk.

What are the implications for public health practice?

Public health officials should raise awareness of risks associated with untreated ground water among users of private wells and of options for private well testing and treatment. Water testing and treatment are important considerations to protect persons who use these unregulated systems from HAV infection.

routine childhood immunization program and microbial drinking water regulations for public water systems. The degree to which these interventions have contributed to the decline in outbreaks is uncertain. However, waterborne outbreak surveillance data is not yet finalized for 2018, and the recent increase in person-to-person transmission of hepatitis $\mathrm{A}(7,8)$ has the potential to cause a resurgence in waterborne outbreaks through increased fecal HAV contamination of private ground water supplies. Outbreak data suggest that individual water systems, primarily those systems drawing untreated ground water from wells, pose the highest risk for causing drinking water-associated hepatitis A outbreaks. These systems are not regulated by USEPA; CDC recommends that owners evaluate their well water quality at least yearly. If indicators of fecal contamination are detected, remediation and treatment of private well water is recommended. Guidance on private well testing and treatment solutions for microbial contamination is provided by USEPA (https://www.epa.gov/privatewells/ protect-your-homes-water) and CDC (https://www.cdc.gov/ healthywater/drinking/private/wells/index.html). Although the current nationwide outbreak of hepatitis A is not waterassociated, considering ground water as a possible transmission route is warranted during community-wide outbreaks of hepatitis A. Ground water can be contaminated with HAV during community transmission of hepatitis $\mathrm{A}$, increasing the risk for persons using untreated water. Public health education about the risks associated with drinking untreated ground water from individual systems, as well as relevant safety measures (i.e., water testing, water treatment, and vaccination), is needed to prevent future drinking water-associated hepatitis A outbreaks.

\section{Acknowledgments}

State, territorial, and local waterborne disease coordinators, epidemiologists, and environmental health personnel; Elyse Phillips, Allison D. Miller, Division of Foodborne, Waterborne, and Environmental Diseases, National Center for Emerging and Zoonotic Infectious Diseases, CDC.

Corresponding author: Catherine E. Barrett, ohi6@cdc.gov, 404-718-7664.

\begin{abstract}
${ }^{1}$ Waterborne Disease Prevention Branch, Division of Foodborne, Waterborne and Environmental Diseases, National Center for Emerging and Zoonotic Infectious Diseases, CDC; ${ }^{2}$ Division of Viral Hepatitis, National Center for HIV/AIDS, Viral Hepatitis, STD, and TB Prevention, CDC; ${ }^{3}$ Office of Ground Water and Drinking Water, U.S. Environmental Protection Agency, Washington, D.C.
\end{abstract}

All authors have completed and submitted the International Committee of Medical Journal Editors form for disclosure of potential conflicts of interest. No potential conflicts of interest were disclosed.

\section{References}

1. Craun GF, Brunkard JM, Yoder JS, et al. Causes of outbreaks associated with drinking water in the United States from 1971 to 2006. Clin Microbiol Rev 2010;23:507-28. https://doi.org/10.1128/CMR.00077-09

2. Wallender EK, Ailes EC, Yoder JS, Roberts VA, Brunkard JM. Contributing factors to disease outbreaks associated with untreated groundwater. Ground Water 2014;52:886-97. https://doi.org/10.1111/ gwat. 12121

3. Biziagos E, Passagot J, Crance JM, Deloince R. Long-term survival of hepatitis A virus and poliovirus type 1 in mineral water. Appl Environ Microbiol 1988;54:2705-10.

4. CDC. Viral hepatitis surveillance, United States 2016. Atlanta, GA: US Department of Health and Human Services, CDC; 2017. https://www.cdc. gov/hepatitis/statistics/2016surveillance/pdfs/2016HepSurveillanceRpt.pdf

5. Fiore AE, Wasley A, Bell BP. Prevention of hepatitis A through active or passive immunization: recommendations of the Advisory Committee on Immunization Practices (ACIP). MMWR Recomm Rep 2006;55(No. RR-7). https://www.cdc.gov/mmwr/preview/mmwrhtml/rr5507a1.htm

6. Ly KN, Klevens RM. Trends in disease and complications of hepatitis A virus infection in the United States, 1999-2011: a new concern for adults. J Infect Dis 2015;212:176-82. https://doi.org/10.1093/infdis/jiu834

7. Foster M, Ramachandran S, Myatt K, et al. Hepatitis A virus outbreaks associated with drug use and homelessness-California, Kentucky, Michigan, and Utah, 2017. MMWR Morb Mortal Wkly Rep 2018;67:1208-10. https://doi.org/10.15585/mmwr.mm6743a3

8. Foster MA, Hofmeister MG, Kupronis BA, et al. Increase in hepatitis A virus infections-United States, 2013-2018. MMWR Morb Mortal Wkly Rep 2019;68:413-5. https://doi.org/10.15585/mmwr.mm6818a2

9. Murphy H, Prioleau M, Borchardt M, Hynds P. Review: epidemiological evidence of groundwater contribution to global enteric disease, 19482015. Hydrogeol J 2017;25:981-1001. https://doi.org/10.1007/ s10040-017-1543-y 